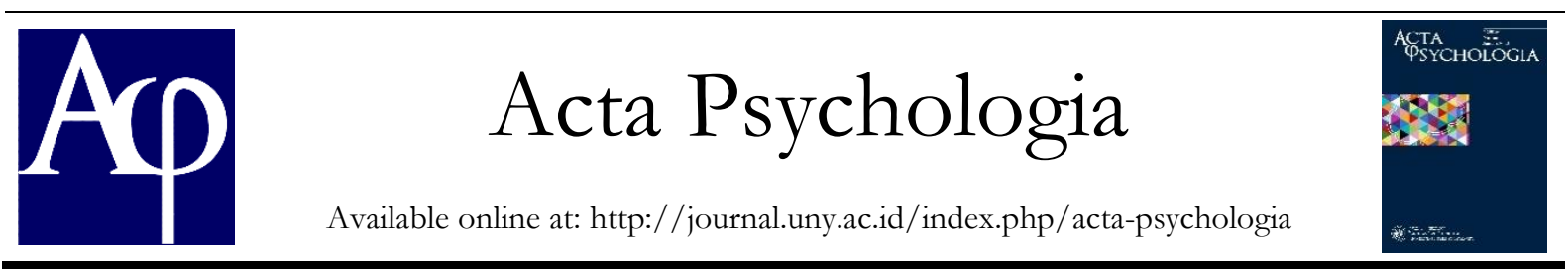

\title{
Strategi Coping pada Mahasiswa Ditinjau dari Big Five Personality
}

\author{
Risqa Fuji Lestari \\ Jurusan Psikologi, Fakultas Ilmu Pendidikan, Universitas Negeri Yogyakarta; \\ Jl. Colombo No. 1 Sleman Yogyakarta, 55281 \\ risqafujilestari@gmail.com
}

\begin{abstract}
Abstrak
Penelitian ini bertujuan untuk mengetahui hubungan kepribadian dan strategi coping jenis problem-focused coping (PFC) dan emotion-focused coping (EFC). Penelitian ini mengambil sampel 422 mahasiswa di Universitas Negeri Yogyakarta. Pengambilan sampel dilakukan dengan teknik multi stage random sampling. Pengumpulan data dalam penelitian ini dilakukan dengan menggunakan skala COPE Inventory dan Big Five Inventory. Hasil penelitian menunjukkan bahwa strategi coping PFC maupun strategi coping EFC berhubungan dengan semua tipe kepribadian. Hal tersebut ditunjukkan dengan adanya hubungan positif antara stategi coping PFC mupun strategi coping EFC dengan tipe kepribadian extraversion, agreeableness, conscientiousness, neuroticism, dan openness dengan nilai signifikansi $\mathrm{p}<0,05$. Hal ini menunjukkan bahwa strategi atau cara seseorang menyelesaikan masalah baik dengan menghadapi masalah ataupun menggunakan emosi berhubungan positif dengan semua tipe kepribadian.
\end{abstract}

Kata Kunci: strategi coping, mahasiswa, kepribadian

\begin{abstract}
This study aims to determine the relationship between personality and coping strategies of problem-focused coping (PFC) and emotion-focused coping (EFC). The sample of this study was 422 students at Universitas Negeri Yogyakarta. The sampling was taken by using multi-stage random sampling technique. Data collection in this study was carried out using the COPE Inventory scale and the Big Five Inventory scale. The results showed that both the PFC coping strategy and the EFC coping strategy related with all personality types. This is indicated by a positive relationship between PFC coping strategies and EFC coping strategies with extraversion, agreeableness, conscientiousness, neuroticism, and openness personality types with a significance value of $\mathrm{p}<0.05$. This study shows that a person's strategy of solving problems either by facing problems or using emotions is positively related to all personality types.
\end{abstract}

Keywords: personality, coping strategy, college student

\section{Pendahuluan}

Mahasiswa merupakan sebuah status bagi individu yang menjalani studi di jenjang perguruan tinggi. Umumnya mahasiswa didominasi oleh individu dewasa awal. Masa dewasa awal adalah masa transisi dari masa remaja menuju masa dewasa yang terletak pada rentang usia 18 tahun hingga 25 tahun (Arnett \& Tranner, 2006). Masa dewasa awal merupakan masa penyesuaian diri terhadap pola dan harapan kehidupan baru di mana individu perlu melakukan penyesuaian diri dengan banyak hal baru yang akan atau sedang terjadi (Hurlock, 1996). Pada periode panjang ini individu akan mencoba berbagai hal baru seperti memulai sebuah 
usaha, bekerja, merantau jauh dari orangtua, dan menikah. Individu mulai memilih dan mengatur hidupnya sedemikian rupa agar sesuai dengan harapannya. Tidak jarang pada saat proses pencarian ini individu menemui konflik. Konflik atau permasalahan yang terjadi berupa tuntutan dari luar maupun dalam diri individu tersebut.

Konflik dari luar diri individu dapat berupa masalah sosial. Masalah sosial adalah hal-hal yang menyangkut nilai-nilai sosial dan moral dimana masalah tersebut menjadi sebuah persoalan karena menyangkut tata kelakuan yang immoral, berlawanan dengan hukum, dan bersifat merusak (Seokanto, 2012). Individu dituntut untuk melakukan hal-hal yang sesuai dengan nilai sosial dan moral dalam bereksplorasi maupun bereksperimen. Berdasarkan konflik dari luar diri individu yang telah dijelaskan, dapat diketahui bahwa tuntutan bisa muncul dari masalah sosial ataupun tuntutan lingkungan kepada individu. Individu diharapkan dapat hidup sesuai dengan nilai dan norma yang berlaku, dan mampu mandiri dalam kehidupan sehari-hari.

Tuntutan muncul tidak hanya dari luar, tetapi juga dari dalam diri individu dewasa awal yaitu berupa tugas perkembangan. Menurut Papalia \& Feldman (2014) tugas perkembangan dewasa awal ialah tugas perkembangan identitas pada masa peralihan remaja ke dewasa, mengembangkan hubungan dewasa dengan orang tua, perkembangan kepribadian menuju kematangan, fondasi hubungan intimasi seperti cinta dan persahabatan, gaya hidup menikah atau tidak menikah, masa sebagai orang tua, dan ketika pernikahan berakhir akibat perceraian atau ditinggal mati. Tugas perkembangan dewasa awal tersebut dapat menjadi tekanan bagi individu jika tidak dilaksanakan dengan baik.
Tekanan dari konflik atau permasalahan tersebut membuat individu berusaha menyesuaikan ataupun menyelesaikan masalah yang ada. Penyelesaian masalah yang kurang efektif dapat menimbulkan stres. Berbagai macam masalah atau tekanan yang timbul dalam hidup manusia pun dapat menimbulkan stres. Menurut Taylor (2012) stres merupakan kondisi memaknai bahwa suatu kejadian adalah sebagai hal yang membahayakan, menantang, atau mengancam individu. Efek yang dimunculkan oleh stres mengakibatkan individu menjadi lebih rentan terhadap infeksi, gangguan pernapasan, jantung, dan menimbulkan distres serta menyebabkan insomnia (Khosla, 2006).

Salah satu dampak dari stres yaitu terjadinya bunuh diri. Sumber lain mengatakan bahwa bunuh diri adalah penyebab utama kedua kematian di kalangan pemuda yang berusia anatara 15 tahun hingga 29 tahun, setelah kecelakaan di jalan, dan di kalangan remaja putri berusia 15 tahun hingga 19 tahun merupakan pembunuh terbesar kedua setelah saat kelahiran (www.cnnindonesia.com).

Kematian karena bunuh diri merupakan salah satu contoh kasus yang disebabkan oleh stres. Beberapa kondisi yang telah dijelaskan sebelumnya, dapat diketahui bahwa individu melakukan berbagai usaha yang dapat mengurangi, menghilangkan, dan meredakan berbagai tekanan yang dialaminya. Berbagai usaha yang dilakukan guna mengatasi tekanan tersebut dikenal dengan istilah coping (Lazarus, 1991). Strategi coping merupakan sebuah label yang diberikan ketika orang merespon persepsi ancaman, bahaya, dan kehilangan dalam beragam cara (Carver \& Connor-Smmith, 2010). Coping diartikan sebagai proses kepribadian dalam aksi di bawah tekanan yang dilakukan individu baik secara kognitif maupun perilaku sebagai proses individu dalam mengelola 
sumberdaya yang ada disekitarnya guna mencegah, mengurangi, dan/atau mengatasi tuntutan, ancaman, bahaya, dan kehilangan yang berasal dari dalam maupun luar individu dalam menghadapi stres (Bolger, 1990, Lazarus \& Folkman, 1984; Taylor, 2014; Lazarus, 1991, 1999; Compas et al. 2001 dalam Carver \& Connor-Smith, 2010). Berdasarkan pemaparan di atas, coping dapat diartikan sebagai sebuah proses kepribadian yang di dalamnya terdapat usaha sadar yang dilakukan secara kognitif maupun perilaku oleh seorang individu guna mencegah, mengurangi, maupun mengatasi berbagai macam tekanan.

Carver, Scheier dan Weintraub (1989) membagi strategi coping menjadi empat dimensi atau empat jenis, yaitu problem-focused coping, emotion-focused coping, less useful, dan recently developed. Problem-focused coping digunakan untuk mengurangi stresor maupun mengatasi stres melalui pemecahan yang melibatkan keterampilanketerampilan atau cara tertentu (Lazarus et al, 1984). Emotion-focused coping digunakan dalam situasi dimana individu tidak mampu mengubah kondisi yang penuh dengan stres dan mengatur respon emosional terhadap stres (Lazarus et al, 1984). Dysfunctional coping atau berbagai bentuk coping jenis ini bersifat merusak dan tidak memberikan manfaat atau dampak yang positif. Recently developed adalah coping yang dilakukan dalam bentuk humor ataupun penggunaan obat-obatan. Berdasarkan pemaparan di atas, peneliti akan menggunakan dua dimensi coping yaitu problem-focused coping dan emotion-focused coping.

Alasan penggunaan problem-focused coping dan emotion-focused coping karena hasil uji lapangan pada 422 subjek, terdapat dua dimensi coping yang sering digunakan, yaitu problem-focused coping dan emotion-focused coping. Oleh karena itu, peneliti memutuskan untuk menggunakan dua dimensi coping sesuai dengan hasil uji lapangan bahwa terdapat banyak subjek sering menggunakan problem-focused coping dan emotion-focused coping.

Berkaitan dengan coping, Taylor (2014) menyebutkan bahwa karakteristik kepribadian membawa setiap orang pada persitiwa stres yang memengaruhi bagaimana individu tersebut mengatasi sebuah peristiwa. Individu yang dalam keadaan tertekan akan menyelesaikan masalah sesuai dengan karakteristik kepribadiannya. Oleh karena itu, kepribadian memengaruhi seseorang dalam melakukan strategi coping.

$$
\text { Menurut Lazarus (1961) }
$$

kepribadian adalah suatu pola atau organisasi disposisi yang disebabkan karena adanya penyebab dari luar diri yang memengaruhi perilaku. Tanpa memahami kepribadian seseorang kita tidak dapat sepenuhnya memahami perilakunya (Lazarus, 1961). Kepribadian dapat memprediksi apa yang akan seseorang lakukan dalam situasi tertentu dan meliputi semua sifat atau karakteristik yang relatif permanen yang menyebabkan konsistensinya suatu perilaku manusia (Margolang \& Kolipaking, 2017). Salah satu teori besar mengenai kepribadian, yaitu kepribadian big five yang merupakan istilah yang dipelopori oleh Leiss Goldberg pada tahun 1981 untuk analisis faktor dari sifat kepribadian (Jess \& Gregory, 2010 dalam Margolang \& Kolipaking, 2017).

Teori big five kemudian dikembangkan menjadi sebuah teori Five Factor Model oleh Robert McCrae \& Paul Costa Jr pada tahun 1985. McCrae \& Costa melakukan analisis faktor yang menemukan bahwa trait atau kata sifat yang dirangkum oleh Cattel dapat dikelompokkan ke dalam lima faktor kepribadian, yaitu extraversion (E), agreeableness $(\mathrm{A})$, openness $(\mathrm{O})$, conscientiousness (C), dan neuroticism (N) (Pervin, 2005). Tipe kepribadian big five memiliki pola kecenderungan dan strategi coping yang 
berbeda. Secara keseluruhan terdapat tipe kepribadian $\mathrm{E}, \mathrm{C}$, dan $\mathrm{O}$ yang cenderung berasosiasi dengan engagement coping, tipe $\mathrm{A}$ dan C memiliki korelasi negatif terhadap disengagement coping, dan tipe $\mathrm{N}$ berkorelasi positif dengan disengagement coping (ConnorSmith \& Flachsbart, 2007).

Penelitian meta-analysis yang dilakukan oleh Connor-Smith \& Flachsbart (2007) menunjukkan bahwa dari lima kepribadian Big Five Personality memiliki pola strategi coping yang khas. Ditunjukkan dengan kepribadian neuroticism memiliki korelasi dengan disengagement coping ( $\mathrm{r}=$ $0,27)$, withdrawal $(\mathrm{r}=0,29)$, avoidance $(\mathrm{r}=$ $0,13)$, dan denial $(\mathrm{r}=0,18)$. Kepribadian neuroticism memiliki respons emosional dan fisik yang intens terhadap stres yang menyebabkan individu untuk berusaha meminimalisir unpleasant arousal yang muncul melalui disengagement coping seperti wishful thinking, withdrawal dan denial yang menjadi sebab adanya korelasi kepribadian neuroticism dengan disengagement coping, withdrawal, avoidance, dan denial. Studi lain mengenai strategi coping adalah studi pada mahasiswa Kwara State University yang dilakukan pada tahun 2013 untuk mengetahui hubungan strategi coping dan kepribadian dengan prestasi mahasiswa. Ditemukan dari 240 subjek sebanyak 53\% (127 subjek) menggunakan problem-focused coping dalam menghadapi stres akademik dan $\quad 47 \% \quad(113$ subjek $)$ lainnya menggunakan emotion-focused coping dalam menghadapi stres akademik. Penelitian ini membuktikan bahwa tipe kepribadian A cenderung lebih berprestasi dan mahasiswa yang menggunakan problem-focused coping juga cenderung lebih berprestasi dibandingkan dengan mahasiswa yang menggunakan emotion-focused coping (Saadu dan Adesoka, 2013).

Kedua penelitian mengenai coping dan kepribadian tersebut membuktikan adanya hubungan antara strategi coping dan kepribadian. Hal tersebut yang melatarbelakangi peneliti untuk melakukan penelitian terhadap strategi coping dan kepribadian pada mahasiswa Universitas Negeri Yogyakarta yang diwakili oleh tiga fakultas, yaitu Fakultas Ilmu Pendidikan, Fakultas Bahasa dan Seni, dan Fakultas Teknik dari tujuh fakultas sebagai sampel penelitian. Mahasiswa yang menjadi subjek dalam penelitian ini ialah mahasiswa jenjang D3 dan S1 yang memiliki rentang usia 18 tahun hingga 24 tahun. Penelitian ini bertujuan menguji hipotesis adanya hubungan kepribadian dan strategi coping jenis problem-focused coping (PFC) dan emotionfocused coping (EFC) pada mahasiswa UNY.

\section{Metode Penelitian}

\section{Jenis Penelitian}

Penelitian ini menggunakan pendekatan kuantitatif dengan jenis korelasional.

\section{Waktu dan Tempat Penelitian}

Peneitian dilakukan pada bulan Agustus 2019 sampai bulan Oktober 2020. Penelitian dilakukan di Fakultas Ilmu Pendidikan, Fakultas Bahasa dan Seni, dan Fakultas Teknik Universita Negeri Yogyakarta.

\section{Populasi dan Sampel Penelitian}

Jumlah populasi pada penelitian ini sebanyak 10.428 mahasiswa. Sampel pada penelitian ini sebanyak 450 mahasiswa.

Prosedur

Penelitian ini terdiri dari beberapa tahap. Tahap pertama adalah penyebaran instrumen (skala strategi coping dan skala kepribadian) kepada 450 mahasiswa di usia dewasa awal. Tahap kedua adalah seleksi item dan reliabilitas. Seleksi item dilakukan dengan menggunakan bantuan program IBM SPSS (Statistical Product and Service Solution) Statistics for Windows 21. Kriteria pemilihan item berdasarkan item total menggunakan batasan $\geq 0,30$. Hal tersebut sesuai dengan pendapat Azwar (2015) bahwa batasan minimal keofisien korelasi item total sebesar 0,30 namun batas 
tersebut dapat dipertimbangkan untuk diturunkan menjadi 0,20 apabila jumlah butir yang lolos masih tidak mencukupi jumlah yang diinginkan.

\section{Data, Instrumen, dan Teknik Pengumpulan} Data

Teknik pengumpulan data pada penelitian ini menggunakan data yang diperoleh langsung dari subjek penelitian. Data penelitian diperoleh melalui 2 instrumen penelitian yang. Instrumen yang digunakan dalam penelitian yang digunakan adalah skala strategi coping dan skala kepribadian. Skala strategi coping tediri dari 38 item dan skala kepribadian terdiri dari 44 item.

\section{Teknik Analisis Data}

Teknik analisis data yang digunakan dalam penelitian adalah analisis deskriptif dan uji hipotesis. Analisis deskriptif meliputi analisis deskriptif subjek dan kategori variabel. Uji hipotesis dilakukan melalui analisis korelasi.

\section{Hasil Penelitian dan Pembahasan}

Hasil dari penelitian ini terdiri dari data statistic masing-masing variabel, dan hubungan antara tiga variabel. Berdasarkan hasil analisis karakteristik subjek, ditemukan data sebagai berikut (dapat dilihat pada Tabel 1.

Tabel 1. Deskripsi Jenis Kelamin Subjek

\begin{tabular}{ccc}
\hline Jenis Kelamin & Jumlah & Presentase \\
\hline Laki-laki & 118 & $28 \%$ \\
Perempuan & 304 & $72 \%$ \\
Jumlah & $\mathbf{4 2 2}$ & $\mathbf{1 0 0 \%}$ \\
\hline
\end{tabular}

$$
\text { Hasil deskriptif kategorisasi }
$$
variabel yang diperoleh data seperti yang ditunjukkan pada Gambar 1 dan Gambar 2. Dapat disimpulkan bahwa mayoritas mahasiswa Universitas Negeri Yogyakarta rata-rata memiliki kategori sedang pada setiap kepribadian dari jumlah sampel yang berjumlah 442 orang mahasiswa. Mayoritas mahasiswa Universitas Negeri Yogyakarta cenderung berada pada kategori sedang untuk jenis strategi coping PFC dan EFC.

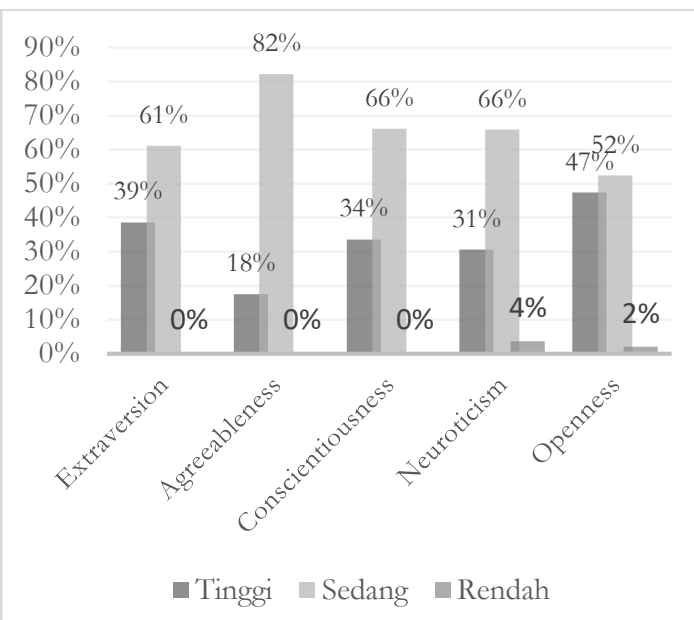

Gambar 1. Grafik Kategorisasi Kepribadian

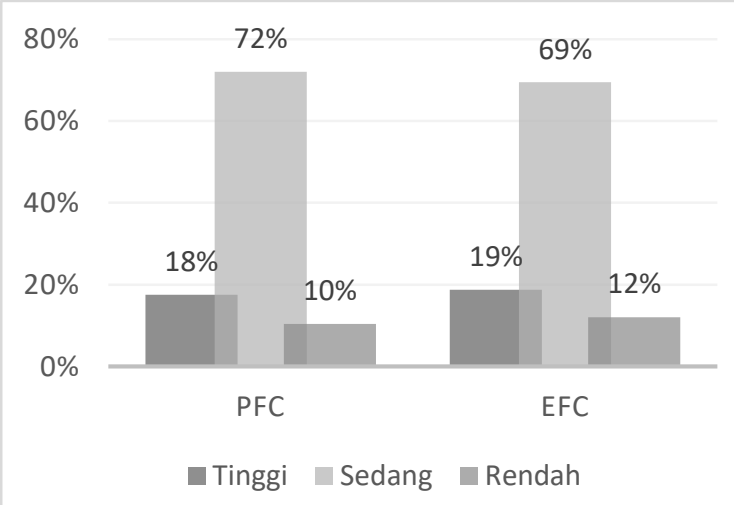

Gambar 2. Grafik Kategorisasi Strategi Coping

Tabel 2. Hasil Uji Korelasi

\begin{tabular}{lccccc}
\hline Variabel & $\mathrm{E}$ & $\mathrm{A}$ & $\mathrm{C}$ & $\mathrm{N}$ & $\mathrm{O}$ \\
\hline PFC & $.408^{* *}$ & $.280^{* *}$ & $.345^{* *}$ & $.109^{*}$ & $.451^{* *}$ \\
$\mathrm{EFC}$ & $.433^{* *}$ & $.263^{* *}$ & $.246^{* *}$ & $.143^{* *}$ & $.350^{* *}$ \\
\hline *signifikan pada $\mathrm{p}<0,05$ & & & \\
**signifikan pada $\mathrm{p}<0,01$ & & &
\end{tabular}

Hasil uji korelasi juga menunjukkan bahwa terdapat hubungan positif antara strategi coping PFC dan strategi coping EFC dengan kepribadian extraversion, agreeableness, conscientiousness, neoroticsm, dan openness. Secara keseluruhan ada hubungan antara strategi coping PFC dan strategi coping EFC 
dengan dimensi-dimensi kepribadian dengan

Hasil analisis deskriptif dari kepribadian bahwa mahasiswa UNY yang memiliki kepribadian agreeableness, conscientiousness, dan openness cenderung mengunakan strategi coping PFC daripada strategi coping EFC. Hal tersebut menunjukkan bahwa mahasiswa UNY dengan kepribadian tersebut cederung menyelesaikan masalah atau mengatasi situasi menekan dengan menggunakan coping yang berfokus pada penyelesaian masalah atau cara mengatasi situasi menekan. Sedangkan mahasiswa UNY dengan kepribadian extraversion cenderung melakukan coping yang berfokus pada emosi. Adapun kepribadian neuroticism tidak memiliki korelasi terhadap kecenderungan melakukan coping PFC ataupun EFC.

Mahasiswa yang memiliki kepribadian agreeableness akan cenderung melakukan coping PFC karena seseorang dengan kepribadian ini cenderung memiliki rasa toleran, percaya, dan hati yang lunak. Seseorang dengan kepribadian agreeableness akan dapat melihat suatu situasi dengan pemikiran yang terbuka karena memiliki rasa toleransi yang tinggi serta kepercayaan. Rasa toleran yang tinggi dapat membuat seseorang dengan kepribadian ini jauh dapat lebih memaklumi situasi dan kondisi yang terjadi.

Mahasiswa dengan kepribadian conscientiousness cenderung menggunakan strategi coping PFC karena memiliki karakter dapat diandalkan, terorganisir, menyeluruh, bertanggung jawab, tekun, bekerja keras, dan senang mencapai dan menyelesaikan berbagai hal. Berdasarkan karakter tersebut sesuai dengan aspekaspek strategi coping PFC, yaitu active coping atau megambil langkah untuk mengurangi atau menyelesaikan suatu masalah yang berhubungan dengan karakter dapat diandalkan sehingga mengambil langkah pasti. Planning sesuai dengan karakter terorganisir yang senang merencanakan dan mempersiapkan berbagai hal dan upaya guna mengatasi situasi, supression of competing activities juga sesuai dengan karakter tekun karena fokus hanya pada penyelesaian masalah atau situasi menekan - Restraint coping dan instrmental social support sesuai dengan karakter bekerja keras dan senang mencapai dan menyelesaikan berbagai hal di mana seseorang dengan kepribadian ini akan cenderung mencari bantuan dalam bentuk dukungan moril maupun lainnya.

Kepribadian openness yang cenderung lebih menggunakan strategi coping PFC. Kepribadian ini memiliki karakter yang menonjol pada minat yang luas dan bersedia mengambil risiko, memiliki pemikiran terbuka, kreatif, imajinatif, dan intelegensi. Seseorang yang memiliki minat yang luas serta besedia mengambil risiko akan jauh lebih beani daam mengambil langkah untuk mengurangi masalah atau situasi menekan. Karakter dengan pemikiran terbuka juga selaras dengan aspek startegi coping PFC, yaitu planning atau berpikir dan merencanakan sesuatu. Tingkat intelegensi yang tinggi juga sesuai dengan aspek startegi coping PFC, yaitu supression of competing activities.

Satu-satunya kepribadian pada mahasiwa UNY yang cenderung menggunakan strategi coping EFC ialah kepribadian extraversion. Kepribadian ini memiliki karakter asertif, suka berteman, senang berbicara, memiliki interaksi ssial yang tinggi juga aktif. Karakter-karakter tersebut ternyata tidak membuat mayoritas mahasiswa UNY dengan kepribadian extraversion lebih memilih strategi coping PFC. Aspek positive reinterpretation atau menginterpretasi ulang stresor menjadi lebih positif berhubungan denga karakter suka berteman.hal tersebut yang membuat seseorang dengan kepribadian ini dapat memiliki teman dan interaksi sosial yang tinggi juga aktif kaena dapat berlawanan dengan karakter asertif yang cenderung 
menyampaikan segala sesuatu yang dipikirkan dan dirasa baik ataupun buruk. Aspek emotion social supportatau mencari simpati dari orang lain juga berhubungan dengan karakter kepribadian extraversion yang memilki interaksi sosial yang tinggi juga aktif.

Satu kepribadian lain yang tidak memiliki kecenderungan dalam pemilihan strategi coping PFC dan strategi coping EFC namun memiliki hubungan dengan kedua strategi coping tersebut, yaitu kepribadian neuroticism. Kepribadian ini memiliki karakter keadaan emosi yang positif seperti merasa aman secara psikologis, tenang juga santai, di lain sisi juga memiliki kecemasan, depresi, kemarahan, dan adanya rasa malu. Hal tersebut karena karakter dari kepribadian ini cukup mewakili atau saling berhubungan kedua strategi coping PFC dan strategi coping EFC.

\section{Simpulan dan Saran}

\section{Simpulan}

Berdasarkan hasil penelitian yang telah dilakukan dapat di ambil kesimpulan bahwa tedapat hubungan positif antara strategi coping dengan kepribadian. Hal tesebut dibuktikan dengan adanya hubungan positif pada strategi oping PFC dan strategi coping EFC dengan semua dimensi kepribadian. Oleh karena itu, dapat disimpulkan bahwa strategi atau cara seseorang menyelesaiakan masalah baik dengan menghadapi masalah ataupun menggunakan emosi berhubungan positif dengan semua dimensi atau bentuk kepribadian.

Saran

Berdasarkan kesimpulan dari penelitian yang telah dilakukan, maka saran yang dapat diberikan yaitu sebagai berikut:

1. Bagi mahasiswa Universitas Negeri Yogyakarta

Mahasiswa diharapkan memilih strategi coping yang dirasa tepat dan sesuai dengan situasi yang sedang dihadapi karena pemilihan strategi coping tidak ada yang baik maupun buruk melainkan waktu pemilihan strategi coping yang tepat atau tidak tepat dalam mengahadapi suatu situasi. Jika menemukan situasi yang dirasa menimbulkan stres dan tidak dapat menemukan pemilihan strategi coping yang tepat, mahasiswa diharapkan untuk langsung menghubungi pembimbing akademik selaku penasihat akademik.

2. Bagi peneliti selanjutnya

Bagi peneliti selanjutnya dapat lebih mengembangkan penelitian ini dengan jumlah sampel yang lebih banyak dan cakupan generalisaso yang luas. Selai itu peneliti selanjutnya daiharapkan dapat mengembangkan penelitian dengan faktor lain yang dinilai dapat memengaruhi terhadap pemilihan strategi coping pada mahasiswa.

\section{Daftar Pustaka}

Arifin, Zainal. (2009). Evaluasi pembelajaran. Bandung: PT. Remaja Rosdakarya.

Azwar, S. (1992). Reliabilitas dan validitas. Yogyakarta: Pustaka Pelajar.

Azwar, S. (2003). Reliabilitas dan validitas. Yogyakarta: Pustaka Pelajar.

Azwar, S. (2007). Metode penelitian (edisi 4). Yogyakarta: Pustaka pelajar.

Azwar, S. (2015). Validitas dan reliabilitas (edisi 4). Yogyakarta: Pustaka Pelajar.

Azwar, S. (2016). Metode penelitian. Yogyakarta: Pustaka Pelajar.

Arnett, J. J., \& Tanner, J. L. (2006). Emerging adults in America: Coming of age in 21st century. Ashington DC: American Psychology Association.

Bolger, N. (1990). Coping as a personality process: a prospective study. Journal 
of Personality and Social Psychology, 59(3), 525-571.

Carver, C. S., Scheier, M. F., \& Weintraub, J. K. (1989). Assesing coping strategies: A theoretically based approach. Journal of Personality and Social Psychology, 56, 267-283.

Carver, Charles S., \& Connor-Smith, J.K. (2010). Personality and coping. Annual Review Psychology, 61, 679-704.

Chaplin, J.P. (2014). Kamus lengkap psikologi. Jakarta: Rajawali Pers.

Connor-Smith, J.K., \& Flachsbart, C. (2007). Relations between personality and coping: A MetaAnalysis. Journal of Personality and Social Psychology, 93(6), 1080-1107. DOI:10.1037/0022-314.93.6.1080

Hurlock, E.B. (1996). Psikologi perkembangan. Jakarta: Erlangga.

Hurlock, E.B. (2007). Psikologi perkembangan suatu pendekatan sepanjang rentang kehidupan edisi kelima. Jakarta: PT Erlangga.

John, O.P., \& Srivastava, S. (1999). The bigfive trait taxonomy: history, measurement, and theoretical perspective. In. L.A. Pervin \& O.P. John (Edit), Handbook of Personality: Theory and research (Vol 2, pp. 102-138). New York: Guildford Press.

Kaur, R., Chodagiri, V.K., \& Reddi, N.K. (2013). A psychological study of stress, personality, and coping in police personnel. Indian Journal of Psychologycal Medicine, 35(2), 185-192.

Khosla, M. (2006). Positive affect and coping with stress. Journal of the Indian Academy of Applied Psycholoogy, 32(2), 185-192.

Lazarus, R.S. (1961). Adjusment personality. New York: McGraw-Hill.
Lazarus, R.S. (1991). Cognition and motivation in emotion. American Psychologist 46, 325-367.

Lazarus, R.S. \& Folkman, S. (1984). Stress, appraisal and coping. New York; Springer.

Liong, Choong-Yeun \& Yeoh, Hui-Ping. (2011). Relationship between Personality and Coping with Stress among Undergraduates of Universiti Kebangsaan Malaysia. Procedng of The Annual International Conference Syiah Kuala University, 1, 2.

Mappiare, A. (1983). Psikologi orang dewasa bagi penyesuaian dan pendidikan. Surabaya: Usaha Nasional.

Margolang, R.H., Kolopaking, R. (2017) Pengaruh kepribadian big five dan coping stress terhadap kecerdasan emosi pada mahasiswa kedokteran di Jakarta. Journal of Psychology, 22, 255 274.

McCrae, R.R., \& Costa, P.T. (2006). Personality in adulthood, a five factor theory perspective. New York: The Guildford Press.

Monica W. (2013). Hubungan antara kepribadian neuroticism dengan disengagement coping stress (Skripsi).

Papalia, D.E. \& Feldman, R.D. (2014). Human development (perkembangan manusia edisi 12 buku 2). Jakarta: Salemba Humanika.

Papalia, D.E. \& Feldman, R.D. (2015). Menyelami perkembangan manusia. Jakarta: Salemba Humanika.

Pervin, L.A., Cervone, D., \& John, O.P. (2005). Personality: Theory and research. Hoboken. NJ: Wiley.

Saadu, U.T. (2013). Personality types and coping strategies as correlates of students' academic achievement. 
Journal of Educational and Social Research, 3, 17-24.

Santrock, J.W. (2013). Life-span development 14th ed. New York: McGraw-Hill Companies, Inc.

Sindhuja, C.V., Srivastava, J.K., gambhir, S., \& Chaturvedula, S. (2013). A study on trait emotional intelligence and personality type of Indian military pilots: a preliminary study. Ind J Aaerospace Med, 57(1), 1-12.

Soekanto, Soerjono. 2012. Sosiologi suatu pengantar. Jakarta: PT Raja Grafindo Persada.

Sugiyono. (2012). Metode penelitian kuatitatif kualitatif dan R\&D. Bandung: Alfabet.

Sugiyono. (2016). Statistika untuk penelitian. Bandung: Alfabet.

Sundayana. (2015). Statistika penelitian pendidikan. Bandung: Alfabet.

Taylor, S.E. (1999). Health psychology. Boston: McGraw-Hill.

Taylor, S.E. (2012). Health psychology. Singapore: McGraw-Hill.

Taylor, S.E. (2014). Health psychology. Singapore: McGraw-Hill.

Vollrath, M. (2001). Personality and stress. Scandinavian Journal of Psychology, 42, 335-347. 